\title{
Patients' Satisfaction with Pharmaceutical Care and Associated Factors [Letter]
}

Firomsa Bekele (D)

Department of Pharmacy, College of Health Science, Mettu University, Mettu, Ethiopia
Correspondence: Firomsa Bekele Department of Pharmacy, College of Health Science, Mettu University, Mettu, Ethiopia

Email firomsabekele2I@gmail.com

\section{Dear editor}

I read with great interest the published article of Hasen et al describing the patients' satisfaction with pharmaceutical care and associated factors among patients admitted to medical wards in Jimma University Medical Center. As a clinical pharmacy specialist, I appreciate the importance of assessing the patient's satisfaction with the newly implemented clinical pharmacy service in Ethiopia. ${ }^{1}$ In this letter, I suggest the methodological approaches and additional factors that can affect the patient's satisfaction in the result part, which I believe would result in more robust findings of the predictors of patient's satisfaction with the clinical pharmacy service.

The author identifies the seven types of drug-related problems found in the medical wards of Jimma university medical center. Despite the reported studies of high drug-related problems among patients admitted to medical ward of Jimma university medical center, the author didn't assess the impact of drugrelated problem on the patient's satisfaction with pharmaceutical care. ${ }^{2}$ Therefore, I suggest the direct relationship between drugs-related problems and patient satisfaction.

The author Hasen et al found that previous admission was significantly associated with the patients' satisfaction. ${ }^{1}$ This might be due to the patients who had previously been admitted to the hospitals and given the clinical pharmacy service were more likely to have good knowledge and attitude regarding pharmaceutical care that results in increased satisfaction. ${ }^{3}$

The authors identified the seven a type of drug-related problems in which nonadherence was the most prevalent. Despite this, adherence was assessed from patient's chart which was difficult to determine by retrospective reviewing the patient's chart and therefore I believe and expect a huge number of nonadherences if conducted prospectively.

Patient satisfaction is one of the components used to determine the quality of the health-care system. Therefore, patients' satisfaction was related to health-care quality. ${ }^{3,4}$ Globally, providing quality pharmaceutical care service could satisfy the demands of hospitalized patients. ${ }^{5}$ The study did not consider the effects of pharmaceutical care quality on patient satisfaction.

The author Hasen et al had used the unstandardized questionnaire based on the extensive review of previous literature. ${ }^{1}$ I kindly recommended the authors to use the standard and validated tool to assess the pharmaceutical care service like the 
tool prepared by Gourley et al, $2001{ }^{6}$ Additionally, the standard algorithm of the Naranjo adverse drug reaction probability scale should be used. ${ }^{7}$ This is since the pharmaceutical care service provided in the study area was at the infancy stage which was difficult to use the tool from developed countries that fully advanced the pharmaceutical care service.

The author Hasen et al recommends increasing the number of clinical pharmacy staff and collaboration of different health-care workers to enhance the quality of pharmaceutical care service. On top of this, I recommend as the special attention should be given to elderly patients, high level of educational status, naïve admitted patients, patients who had poor socioeconomic status, and poor knowledge of pharmaceutical care despite those variables was not a predictor in the study. ${ }^{3}$

\section{Disclosure}

The author reports no conflicts of interest for this communication.

\section{References}

1. Hasen G, Negeso B. Patients satisfaction with pharmaceutical care and associated factors in the Southwestern Ethiopia. Patient Prefer Adherence. 2021;15:2155-2163. doi:10.2147/PPA.S332489

2. Tigabu BM, Daba D, Habte B. Drug-related problems among medical ward patients in Jimma university specialized hospital, Southwest Ethiopia. J Res Pharm Practice. 2014;3(1):1.PMID: 24991628. doi:10.4103/2279-042X.132702

3. Ismail A, Gan YN, Ahmad N, Suppiah V. Factors associated with patient satisfaction towards pharmacy services among out-patients attending public health clinics: questionnaire development and its application. PLoS One. 2020;15(11):e241082. doi:10.1371/journal. pone. 0241082

4. Ayele Y, Hawulte B, Feto T, et al. Assessment of patient satisfaction with pharmacy service and associated factors in public hospitals, Eastern Ethiopia. SAGE Open Med. 2020;8:1-7. doi:10.1177/2050312120922659

5 . Andaleeb SS. Service quality perceptions and patient satisfaction: a study of hospitals in a developing country. Soc Sci Med. 2001;52 (9):1359-1370. doi:10.1016/S0277-9536(00)00235-5

6. Gourley GK, Gourley DR, Rigolosi ELM, Reed P, Solomon DK, Washington E. Development and validation of the pharmaceutical care satisfaction questionnaire. Am $J$ Manag Care. 2001;7 (5):461-466. PMID: 11388126.

7. Naranjo CA, Busto U, Sellers EM, et al. A method for estimating the probability of adverse drug reactions. Clin Pharmacol Ther. 1981;30 (2):239-245. PMID: 7249508. doi:10.1038/clpt.1981.154

Dove Medical Press encourages responsible, free and frank academic debate. The content of the Patient Preference and Adherence 'letters to the editor' section does not necessarily represent the views of Dove Medical Press, its officers, agents, employees, related entities or the Patient Preference and Adherence editors. While all reasonable steps have been taken to confirm the content of each letter, Dove Medical Press accepts no liability in respect of the content of any letter, nor is it responsible for the content and accuracy of any letter to the editor.

\section{Publish your work in this journal}

Patient Preference and Adherence is an international, peer-reviewed, open access journal that focusing on the growing importance of patient preference and adherence throughout the therapeutic continuum. Patient satisfaction, acceptability, quality of life, compliance, persistence and their role in developing new therapeutic modalities and compounds to optimize clinical outcomes for existing disease states are major areas of interest for the journal. This journal has been accepted for indexing on PubMed Central. The manuscript management system is completely online and includes a very quick and fair peer-review system, which is all easy to use. Visit http:// www.dovepress.com/testimonials.php to read real quotes from published authors. 